\title{
Hemostatic Factors and Its Correlation with Outcomes of COVID-19 Confirmed Patients in Ulin Regional Hospital Banjarmasin
}

\author{
Nadia Muslimah Annisa*1, Desi Rahmawaty ${ }^{1,}$ Haryati $^{2}$, Ira Nurrasyidah ${ }^{2}$ \\ ${ }^{1}$ Medical Faculty, Lambung Mangkurat University, Banjarmasin, Indonesia \\ ${ }^{2}$ Department of Pulmonology and Respiratory Medicine, Medical Faculty, Lambung Mangkurat University, Ulin Regional
} Hospital, Banjarmasin, Indonesia

\section{ARTICLE INFO}

*Corresponding author

Email:

nadiamuslimahannisa@yahoo.com

Address:

Jl. Veteran No 128, Banjarmasin, South

Kalimantan

Keywords:

COVID-19; coagulopathy; hemostatic factor; outcome

Manuscript submitted: January 21, 2021

Revised and accepted: August 28, 2021

\begin{abstract}
Background: Corona Virus Disease (COVID-19) caused by Severe Acute Respiratory Syndrome Coronavirus (SARS-CoV-2) has become a Global Pandemic and has spread to more than 200 countries including Indonesia. Previous studies show that poor prognosis has a correlation with coagulopathy conditions.
\end{abstract}

Objectives: To identify coagulopathy condition and its correlation with the outcomes of COVID-19 confirmed patients at Ulin Regional Hospital Banjarmasin as referral hospital in South Kalimantan.

Methods: A retrospective study by extracting demographic, clinical and laboratory data from medical record of patients confirmed with COVID-19 at Ulin Regional Hospital Banjarmasin period March-August 2020, compared survival versus non survival groups and logistic regression test was conducted.

Results: This study showed from 309 COVID-19 confirmed patients, there were $239(77.3 \%)$ survival case and $70(22.7 \%)$ non survival case with the median of age 50 years old and $151(51,8 \%)$ were man. PT, APTT, INR value and D-Dimer level significantly higher (P value $<0,005$ ) in non-survival case (11.9s; 31.0s, 1.1, $4.5 \mathrm{mg} / \mathrm{L})$ than survival case $(11.2 \mathrm{~s}, 28.3 \mathrm{~s}, 1.0,1.4 \mathrm{mg} / \mathrm{L})$, while the platelet count has no significant difference ( $\mathrm{P}$ value $>0,005$ ). Regression test showed the increase of D-dimer level and APTT have significant correlation with the outcome of COVID-19 patient (OR 1.318, 95\% CI $1.173-1.480$, P value $=0.000 ;$ OR $1.101,95 \%$ CI $1.041-1.164$, P value 0.001 )

Conclusions: Most COVID-19 cases cause coagulopathy conditions. However, considering the risk of poor outcomes, further studies should investigate the prognostic role of hemostatic parameters in COVID-19 patients.

\section{INTISARI}

Latar Belakang: Penyakit Virus Corona (COVID-19) yang disebabkan oleh Severe Acute Respiratory Syndrome Coronavirus (SARS-Cov-2) telah menjadi sebuah Pandemi Global dan telah menyebar ke lebih dari 200 negara termasuk Indonesia. Penelitian sebelumnya menunjukkan bahwa prognosis yang buruk pada pasien COVID-19 berkaitan dengan kondisi koagulopati.

Tujuan: Mengidentifikasi kondisi koagulopati serta hubungannya terhadap outcome pada pasien terkonfirmasi COVID-19 di RSUD Ulin Banjarmasin sebagai Rumah Sakit rujukan Propinsi Kalimantan Selatan.

Metode: Data demografis, klinis dan laboratoris diekstraksi dari rekam medis pasien terkonfirmasi COVID-19 di RSUD Ulin Banjarmasin periode 


\begin{abstract}
Maret-Agustus 2020 dan dibandingkan antara kasus survive dan meninggal
\end{abstract} kemudian dilakukan uji analisis regresi logisitik.

Hasil: Dari 309 pasien terkonfirmasi COVID-19, terdapat sebanyak 239 $(77,3 \%)$ kasus survive dan $70(22,7 \%)$ kasus meninggal dengan median usia 50 tahun dan 151 (51,8\%) berjenis kelamin laki-laki. Nilai PT, APTT, INR dan kadar D-dimer secara signifikan ( $\mathrm{P}$ value $<0,005$ ) lebih tinggi pada kasus meninggal $(11,9 \mathrm{~s} ; 31,0 \mathrm{~s} ; 1,1 ; 4,5 \mathrm{mg} / \mathrm{L})$ dibandingkan kasus survive (11,2s; 28,3s; 1,$0 ; 1,4 \mathrm{mg} / \mathrm{L})$ sedangkan nilai trombosit tidak memiliki perbedaan bermakna (P value $>0,005$ ). Uji regresi menunjukkan peningkatan kadar DDimer dan APTT memiliki pengaruh signifikan terhadap outcome pasien COVID-19 (OR 1,318; 95\% CI 1,173 - 1,480; P value = 0,000 and OR 1,101; 95\% CI 1,041-1,164; P value 0,001).

Kesimpulan: Sebagian besar kasus COVID-19 menyebabkan terjadinya kondisi koagulopati. Namun, perlu dilakukan penelitian lebih lanjut terkait hubungan parameter hemostasis dengan prognosis yang buruk pada pasien COVID-19

\section{Introduction}

Novel Coronavirus or now formally referred to as Severe Acute Respiratory Syndrome Coronavirus 2 (SARS-Cov-2) is the cause of Corona Virus Disease 2019 (COVID-19) which has been designated by the World Health Organization (WHO) as a global pandemic.1,2 Since December 2019, COVID-19 has spread rapidly to more than 200 countries including Indonesia. As of 29 October 2020, there were 404,048 confirmed cases of COVID-19 in Indonesia with a Case Fatality Rate (CFR) of 3.4\%. South Kalimantan is one of the provinces in Indonesia that is affected by COVID-19 with a fairly high mortality rate (CFR 4.09\%) exceeding Indonesia's CFR.3,4

Most COVID-19 cases have a good prognosis. However, some of them develop into severe and critical cases such as severe pneumonia, acute respiratory distress syndrome (ARDS), multi-organ failure, sepsis to septic shock which ends in death.5,6,7 Several studies have shown a poor prognosis in COVID-19 patients is associated with coagulopathy conditions indicated by increased fibrinogen and D-dimer levels as well as changes in prothrombine time (PT), activated partial thromboplastin time (aPTT) and platelet counts.7,8,9,10 Bilaloglu S, et al mentioned that COVID-19 is associated with an increased risk of thrombotic events, both vein thrombosis (deep vein thrombosis [DVT] and pulmonary embolism [PE]) and arterial thrombosis (myocardial infarction, ischemic stroke and other systemic thromboembolism).11 Several other studies stated that in COVID-19 case, there was a significant increase in D-dimer levels which were associated with a high risk of thrombosis and poor outcomes.10,12,13 Hypercoagulation was mentioned as an early stage disorder that often occurs and can be identified in cases of COVID-19 related to progressivity and mortality. However, in Indonesia, research related to hemostatic factors and their relationship to outcome in COVID-19 patients is still not widely found.

From March to August 2020, Ulin Regional Hospital Banjarmasin as a COVID-19 Refferal Hospital in South Kalimantan has treated a number of COVID-19 patients. In this study, 309 patients were analyzed to determine the value of hemostatic factors and outcomes of COVID-19 confirmed patients in Ulin Regional Hospital Banjarmasin for the period March-August 2020 with the aim of identifying coagulopathic conditions and their relationship to prognosis in COVID-19 patients. Therefore, we hope that results of this study can help in stratifying the risk of patients with SARS-CoV2 infection, so interventions can be given in a timely manner to avoid disease progression and improve the outcome of patients infected with COVID-19 and reduce the death rate from COVID-19 in the future.

\section{Methods}

This study is a retrospective analysis using demographic, clinical and laboratory data extracted from the medical records of a COVID-19 confirmed patient treated at Ulin Regional Hospital Banjarmasin in the period MarchAugust 2020. A confirmed diagnosis of COVID-19 is defined as a person who is tested positive for the COVID19 virus as confirmed by RT-PCR (reverse-transcriptase polymerase chain reaction) testing method. This study used a purposive sampling method and obtained 309 research subjects. The inclusion criteria for this study were the medical records of all patients with confirmed COVID-19 who were treated in the period March-August 2020 and the exclusion criteria in this study were incomplete medical records according to the specified variables. The independent variables examined in this study were age, sex, onset, symptom, hemoglobin, erythrocyte, leucocyte, platelet, platelet to lymphocyte ratio (PLR), neutrophil to lymphocyte ratio (NLR) and coagulation parameter: D-Dimer, PT, APTT and INR (using the nephelometric method), while the dependent variables of this study were the outcomes: survivor (patients with negative swab results or patients who were discharged for independent isolation due to positive persistence) and non-survivor (death). The data were then collected using a computer program according to a standard form that had been designed beforehand, then tabulated and statistically analyzed using the SPSS program using the Saphiro Wilk normality test, followed by the Mann Whitney test, then the logistic regression 
analysis test. Results are displayed in narrative form, tables and graphs. This study was approved by ethical committee of Ulin Regional Hospital Banjarmasin.
Based on 309 demographic, clinical and laboratory data on confirmed COVID-19 cases treated at Ulin Banjarmasin Hospital for the period March-August 2020, 239 (77.3\%) survival case and $70(22.7 \%)$ non survival cases died with the characteristic shown in Table 1 and laboratory finding shown in Table 2.

Results

Table 1. The Characteristic of Patients with Confirmed COVID-19 at Ulin Regional Hospital, Banjarmasin for the Period of March-August 2020

\begin{tabular}{|c|c|c|c|c|}
\hline Characteristics & $\begin{array}{c}\text { Total } \\
n=309\end{array}$ & $\begin{array}{c}\text { Survival } \\
n=239\end{array}$ & $\begin{array}{c}\text { Non-Survival } \\
n=70\end{array}$ & $P$ value \\
\hline $\begin{array}{l}\text { Age in } \\
\text { yr, median (IQR) }\end{array}$ & $50(58-41)$ & $49(57-46)$ & $54(60-44)$ & 0.012 \\
\hline $\begin{array}{l}\text { Sex } \\
\text { Male } \\
\text { Female }\end{array}$ & $\begin{array}{l}160(51.8 \%) \\
149(48.2 \%)\end{array}$ & $\begin{array}{l}111(46.4 \%) \\
128(53.6 \%)\end{array}$ & $\begin{array}{l}49(70 \%) \\
21(30 \%)\end{array}$ & 0.005 \\
\hline $\begin{array}{l}\text { Onset in days, } \\
\text { median (IQR) }\end{array}$ & $5(7-3)$ & $4(7-2)$ & $7(7-3)$ & 0,021 \\
\hline Symptom & & & & - \\
\hline Asymptomatic & $31(10.0 \%)$ & $31(13.0 \%)$ & 0 & \\
\hline Anosmia & $2(0.6 \%)$ & $2(0.8 \%)$ & 0 & \\
\hline Cough & $31(10.0 \%)$ & $27(11.3 \%)$ & $4(5.7 \%)$ & \\
\hline Fever & $60(19.4 \%)$ & $48(20.1 \%)$ & $12(17.1 \%)$ & \\
\hline Seizure & $1(0.3 \%)$ & $1(0.4 \%)$ & 0 & \\
\hline Limb weakness & $2(0.6 \%)$ & $2(0.8 \%)$ & 0 & \\
\hline Fatigue & $10(3.2 \%)$ & $9(3.8 \%)$ & $1(1.4 \%)$ & \\
\hline Nausea and/or vomitus & $6(1.9 \%)$ & $6(2.5 \%)$ & 0 & \\
\hline Chest pain & $1(0.3 \%)$ & $1(0.4 \%)$ & 0 & \\
\hline Headache & $1(0.3 \%)$ & $1(0.4 \%)$ & 0 & \\
\hline Abdominal pain & $2(0.6 \%)$ & $1(0.4 \%)$ & $1(1.4 \%)$ & \\
\hline Sore throat & $3(1.0 \%)$ & $2(0.8 \%)$ & $1(1.4 \%)$ & \\
\hline Decrease of conciousness & $4(1.3 \%)$ & $3(1.3 \%)$ & $1(1.4 \%)$ & \\
\hline Decreased appetite & $3(1.0 \%)$ & $3(1.3 . \%)$ & 0 & \\
\hline Ageusia & $1(0.3 \%)$ & $1(0.4 \%)$ & 0 & \\
\hline Shortness of breath & $151(48.9 \%)$ & $101(42.3 \%)$ & $50(71.4 \%)$ & \\
\hline
\end{tabular}

The characteristics data suggest that the median age was 50 years and $160(51.8 \%)$ were man. The most common initial symptom was shortness of breath (48.9\%) with 5 days of median onset to admission time. The age, sex and onset were compared between survival and non-survival groups and no significant different were found.

Routine blood test, PLR, NLR and coagulation parameter were analyzed in this study. The median of haemoglobin, erythrocyte, leucocyte and platelet count were in normal range (13.2 g/dL, 4,6 x1012/L, 8.4 x109/L, 264 x109/L). The median of PLR and NLR were increase upper the normal range (220 and 5.1). The median of coagulation parameter including PT, APTT, INR and were in normal range $(11.3 \mathrm{~s}, 28.8 \mathrm{~s}, 1)$, but the D-Dimer levels was increase $(1,6 \mathrm{mg} / \mathrm{L})$. Except for platelet count, the increase in routine blood test, PLR, NLR and coagulation parameter value was found to be higher in non-survivor than in survivor cases. Based on the normality test, the data were not normally distributed $(\mathrm{P}<0.005)$ and the Mann Whitney statistical test was performed. Comparison of routine blood count and coagulation parameter shown in Table 2 . NLR, PT, APTT and D-Dimer levels were significantly higher in non-survival than survival.

This study used logistic regression to analyze the outcome of COVID-19 patients. NLR, PT, APTT, INR and D-dimer which have significant differences between survival and non-survival group were included in the regression test (Table 3).

The result of regression test suggests that increase of DDimer levels and APTT may contribute to the death risk of COVID-19 patients in which D-Dimer has odds ratio (OR) $1.318,95 \%$ confidence interval $(\mathrm{CI}) 1.173-1.480$, P value $=0.000$, and APTT has OR 1.101, 95\% CI 1.041-1.164, P value 0.001 . 
Table 2. Laboratory Finding of Patients with Confirmed COVID-19 at Ulin Regional Hospital, Banjarmasin for the Period of March-August 2020

\begin{tabular}{|c|c|c|c|c|c|}
\hline $\begin{array}{l}\text { Laboratory } \\
\text { Finding at Admission }\end{array}$ & $\begin{array}{l}\text { Normal } \\
\text { range }\end{array}$ & $\begin{array}{c}\text { Total } \\
n=309\end{array}$ & $\begin{array}{c}\text { Survival } \\
n=239\end{array}$ & $\begin{array}{c}\text { Non-Survival } \\
n=70\end{array}$ & $P$ value \\
\hline $\begin{array}{l}\text { Haemoglobin } \\
\text { in } \mathrm{g} / \mathrm{dL} \text {, } \\
\text { median (IQR) }\end{array}$ & $14.0-18.0$ & $\begin{array}{c}13.2 \\
(14.5-11.6)\end{array}$ & $\begin{array}{c}13.1 \\
(14.3-11.7)\end{array}$ & $\begin{array}{c}13.3 \\
(15.1-11.6)\end{array}$ & 0.175 \\
\hline $\begin{array}{l}\text { Erythrocytes } \\
\times 1012 / \mathrm{L}, \\
\text { median (IQR) }\end{array}$ & $4.10-6.00$ & $\begin{array}{c}4.6 \\
(5.1-4.1)\end{array}$ & $\begin{array}{c}4.6 \\
(5.1-4.1)\end{array}$ & $\begin{array}{c}4.7 \\
(5.3-4.3)\end{array}$ & 0.074 \\
\hline $\begin{array}{l}\text { Leucocytes } \\
\times 109 / \mathrm{L}, \\
\text { median (IQR) }\end{array}$ & $4.0-10.5$ & $\begin{array}{c}8.4 \\
(11.4-6.3)\end{array}$ & $\begin{array}{c}8.1 \\
(10.6-6.3)\end{array}$ & $\begin{array}{c}10.1 \\
(13.0-6.4)\end{array}$ & 0.073 \\
\hline $\begin{array}{l}\text { Platelet count } \\
\times 109 / \mathrm{L}, \\
\text { median (IQR) }\end{array}$ & $150-450$ & $\begin{array}{c}264.0 \\
(344.0-202.0)\end{array}$ & $\begin{array}{c}269.0 \\
(343.5-207.5)\end{array}$ & $\begin{array}{c}243.0 \\
(344.8-172.5)\end{array}$ & 0.186 \\
\hline $\begin{array}{l}\text { PLR } \\
\text { median (IQR) }\end{array}$ & - & $\begin{array}{c}220.4 \\
(326.7-151.6)\end{array}$ & $\begin{array}{c}215.9 \\
(148.8-308.4)\end{array}$ & $\begin{array}{c}275.0 \\
(170.1-361.4)\end{array}$ & 0.018 \\
\hline $\begin{array}{l}\text { NLR, } \\
\text { median (IQR) }\end{array}$ & - & $\begin{array}{c}5.1 \\
(8.7-3.1)\end{array}$ & $\begin{array}{c}5.0 \\
(7.5-2.8)\end{array}$ & $\begin{array}{c}7.0 \\
(12.4-4.5)\end{array}$ & 0.000 \\
\hline $\begin{array}{l}\mathrm{PT} / \mathrm{s}, \\
\text { median (IQR) }\end{array}$ & $9.9-13.5$ & $\begin{array}{c}11.3 \\
(12.3-10.7)\end{array}$ & $\begin{array}{c}11.2 \\
(12.2-10.6)\end{array}$ & $\begin{array}{c}11.9 \\
(12.7-11.1)\end{array}$ & 0.003 \\
\hline $\begin{array}{l}\text { APTT/s, } \\
\text { median (IQR) }\end{array}$ & $22.2-37.0$ & $\begin{array}{c}28.8 \\
(32.2-26.2)\end{array}$ & $\begin{array}{c}28.3 \\
(31.4-26.1)\end{array}$ & $\begin{array}{c}31.0 \\
(34.6-27.9)\end{array}$ & 0.000 \\
\hline $\begin{array}{l}\text { INR, } \\
\text { median (IQR) }\end{array}$ & - & $\begin{array}{c}1.0 \\
(1.2-1.0)\end{array}$ & $\begin{array}{c}1.0 \\
(1.1-1.0)\end{array}$ & $\begin{array}{c}1.1 \\
(1.2-1.0)\end{array}$ & 0.010 \\
\hline $\begin{array}{l}\text { D-dimer in mg/L, } \\
\text { median (IQR) }\end{array}$ & $<0.22$ & $\begin{array}{c}1.6 \\
(4.5-0.7)\end{array}$ & $\begin{array}{c}1.4 \\
(3.0-0.6)\end{array}$ & $\begin{array}{c}4.5 \\
(6.1-1.4)\end{array}$ & 0.000 \\
\hline
\end{tabular}

Table 3. Logistic Regression Analysis for The Outcome

\begin{tabular}{lccc}
\hline Variabel & OR & $95 \%$ CI & P value \\
\hline NLR & 0.977 & $0.921-1.036$ & 0.441 \\
PT & 1.129 & $0.972-1.312$ & 0.111 \\
APTT & 1.101 & $1.041-1.164$ & 0.001 \\
INR & 0.504 & $0.190-1.334$ & 0.168 \\
D Dimer & 1.318 & $1.173-1.480$ & 0.000 \\
\hline
\end{tabular}

\section{Discussion}

COVID-19 has become a global health problem since the past year. SARS-CoV-2 Infection has been associated with abnormalities of various organ functions including abnormal hemostasis function. Coagulation dysfunction is one of the most common abnormalities and is a problem that has been mentioned in several studies, where it is many associated with the severity of infection, outcome and mortality in patients with COVID-19,14,15,16

Ulin Regional Hospital Banjarmasin as a COVID-19 Refferal Hospital in South Kalimantan has treated a number of COVID-19 patients. In the present of this study
$70(22.7 \%)$ of 309 patients had died. Elderly age and males were more commonly found in the non-survival group, which was consistent with previous study.7,10,19 The most common initial symptom was shortness of breath $(48.9 \%)$ with 5 days of median onset to admission time and might reflect the pulmonary function has begun to be impaired as pneumonia and ARDS which associated with a poor prognosis.5,6 Laboratory finding in show that median of haemoglobin, erythrocyte, leucocyte and platelet count were normal, but PLR and NLR were increase. Median of coagulation parameter on this study including PT, APTT, INR and were also in normal range but the D-Dimer levels was increase as the most consistent result in previous study about coagulation parameters in COVID-19 patients. $7,8,10,14$

In this study, an analysis laboratory data was carried out related to hemostatic factors in the form of platelet count, PT, APTT, INR and D-Dimer levels which indicated coagulopathy condition in most confirmed COVID-19 patients treated at Ulin Regional Hospital, Banjarmasin. Coagulopathy is defined as the inability of blood to form blood clots. Coagulopathy is a pathological processes leading to failure of hemostasis or mechanisms to stop and prevent bleeding. Although the incidence of coagulopathy in COVID-19 cases is not clearly known, coagulopathy associated with COVID-19 has a more complex meaning and has been reported to have a characteristic hemostatic 
picture and is part of the systemic inflammatory response syndrome in severe and critical cases.9,17,18 Several studies suggested that the most common hemostatic abnormalities in COVID-19 cases are minimally prolonged of PT, APTT, INR, with normal platelets count or mild thrombocytopenia and increase in D-dimer and/ or fibrinogen levels. $9,14,16,19,20,21$ However, the coagulopathy condition is actually characterized by more thrombotic events than hemorrhagic events. ${ }^{18}$ In line with the previous study, our study also found similar results, normal platelet values with minimally prolonged PT, APTT, INR and an increase in D-dimer levels in both survivor and non-survivor cases. Gomez-Mesa JE, et al stated that the combination of massive thrombocytopenia, prolonged PT and increased D-dimer in COVID-19 cases can indicate Disseminated Intravascular Coagulation (DIC) condition. ${ }^{9}$ Current studies shows that coagulopathy associated with COVID-19 is a combination of DIC and pulmonary thrombotic microangiopathy which has a significant impact on the majority of organ dysfunction and disease severity. ${ }^{18}$ Tang $\mathrm{N}$, et al in their study mentioned as many as $71.4 \%$ of non-survivor COVID-19 cases and $0.6 \%$ of survivor cases meet DIC criteria during the hospital stay. ${ }^{19}$

In this study, we found that there was an increase in Ddimer levels while platelets, PT, APTT, INR were still tended to be in normal normal limit in both survival and death cases in COVID-19 patients at RSUD Ulin Banjarmasin. Research by Long $\mathrm{H}$, et al and Lippi G, et al also showed a significant increase in D-dimer levels in severe and critical cases of COVID-19 who were treated with hypercoagulable conditions.7,22 Sakka M, et al also stated that D-dimer levels were found to be higher in nonsurvivors compared with survivors and associated with a prothrombotic condition. ${ }^{12} \mathrm{D}$-dimers are the degradation products of fibrin cross-linking produced when plasmin cleaves fibrin to break up blood clots and indicate fibrinolytic activity. ${ }^{13,23}$ Increased D-dimer levels in COVID-19 cases may indicate a hypercoagulable state which may be due to several factors such as: an aggressive pro-inflammatory response with an insufficient antiinflammatory response leading to endothelial cell dysfunction resulting in excess thrombin formation; hypoxic conditions that stimulate thrombosis; existence other factors related to old age, comorbidities, long-term bed rest and invasive treatment are thoserisk factors for hypercoagulation or thrombosis; and the possibility of sepsis or DIC in some patients who develop coagulopathy. 10

Based on the comparative significance test for haemostatic factors, D-dimer levels, PT, APTT and INR values in patients with confirmed COVID-19 at Ulin Regional Hospital Banjarmasin were found to be significantly higher in non-survivor cases than in survivor cases. In line with this result, several previous studies also stated that the value of the hemostasis factor was higher in cases of death than in cases of survival.15,16,22 Tang N, et al in their research stated that D-dimer levels, PT and APTT values were significantly higher in cases of death than in cases of survivors. Lou Hc, et al in their study also showed that the values of PT, APTT, INR, fibrinogen degradation product (FDP) and D-dimer in non-survivors cases were significantly higher than in survivor cases. ${ }^{14}$

In many studies, increased levels D-dimer is one of the most consistent findings and has a significant correlation in hemostasis parameters, especially in severe-critical cases. D-Dimer is often mentioned as a marker of severity and poor outcome in cases of COVID-19,8,10,14,24,25 Berger $\mathrm{JS}$, et al states that an increase in D-dimer $>2000 \mathrm{ng} / \mathrm{mL}$ is associated with the risk of progression of the disease to a critical degree, thrombosis, acute kidney injury (AKI) and death. Similar research by Zhang L, et al also stated that the increase in D-dimer $>2.0 \mu \mathrm{g} / \mathrm{mL}$ on initial admission to the hospital indicates a higher mortality in patients COVID-19.10 In line with the previous study, this study showed that D-dimer levels has significant correlation with the outcome and may contribute to the death risk of COVID-19 patients (OR 1.318, 95\% CI 1.173 - 1.480, $P$ value $=0.000$ ).

On the other hand, there are several similar studies that show no correlation between D-dimer levels and multiple "composite endpoints".14 Multivariate analysis by Rojas RMM, et al showed a weak association between D-dimer levels and mortality in COVID-19 patients. ${ }^{19.15}$ It may be related to several other studies that have confirmed the relevance and factors influence the increase in D-dimer. In several studies it was found that there was a tendency for D-dimers to increase in older age group, female gender, abnormal body mass index (BMI), dyslipidemia condition, pregnancy and history of smoking and alcohol consumption. ${ }^{23.26}$ In addition, other studies suggest that there is a relationship between increased D-dimer and fibrin degradation products in conditions with an activated coagulation system such as thromboembolic disease, cardiovascular ischemic disease, infection, and malignancy. Some chronic inflammatory conditions that can also cause increased D-dimer levels include rheumatoid arthritis, sickle cell disease, and asthma. 26,28

Apart from increasing levels D-dimer, several studies have also stated that PT prolongation has a correlation with severity and prognosis in cases of COVID-19.7,14,15 However in this study, the PT has no significant corellation for the outcome $(P$ value $=0.111)$, but APTT has a significant value (OR 1.101, 95\% CI 1.041 - 1.164, $P$ value $=0.001$ ) . Mentioned in meta-analysis and systematic review studies, PT prolongation was consistently associated with disease severity and was used as a predictor of mortality in COVID-19 patients whereas APTT did not have such a correlation. ${ }^{14,16,29}$ PT and APTT generally experienced prolongation in cases of DIC. However, in COVID-19 most of the cases showed normal PT and APTT values, or only mild lengthening. It was reported that only about $5 \%$ of cases experienced prolonged PT and $6 \%$ of cases experienced prolonged APTT in COVID-19 patients. ${ }^{16}$

The INR is the ratio of the patient's prothrombin time to a normal (control) sample, raised to the rank of the International Sensitivity Index (ISI) value for the analytical system used. Not different from other variables, the INR value in this study has no significant correlation with the 
outcome in COVID-19 patients ( $P$ value $=0.168$ ). Currently, there are not many studies related to INR that have linked the prognosis in COVID-19. However, Luo HC et al stated that there was a significant increase in the INR value in COVID-19 non-survived patients. ${ }^{16}$

In our study, we obtained platelet count has no significant differences between survival cases and non-survival cases $(P$ value $=0.186)$. Therefore, platelet count was not continued with regression test. In line with a metaanalysis study by Luo L, et al, which states that the platelet count statistically has no relationship with the degree of disease severity in COVID-19 patients. ${ }^{14}$ Platelets have an important role in both the hemostasis process and thrombotic events. Activation of platelets and thrombocytosis will increase the risk of thrombotic complications, impaired platelet function and thrombocytopenia which can increase the risk of bleeding. Both thrombocytopenia and reactive thrombocytosis are both common in various viral infections. However, in COVID-19, several reports state that platelet counts within normal limits are often found at the start of treatment, whereas thrombocytopenia is often reported in patients who are severe-critical or non-survivor. ${ }^{14}$

There have been many studies abroad related to hemostatic abnormalities with different variables and outcomes that are associated with prognosis in COVID patients. Most concluded that increased D-dimer and FDP as well as PT prolongation could predict a higher risk stratification and worse prognosis in COVID-19 cases, although it may not be completely in line with the facts as the studies linked to being a meta-analysis are limited. However, it is currently believed that early evaluation and dynamic monitoring of hemostasis indicators during hospitalization will greatly assist in early identification of coagulation disorders, develop a scoring system related to rational use of hemostasis parameters so that they can guide effective treatment and improve the prognosis of COVID-19 patients. ${ }^{15,30,31,32}$

In this study, there are several limitations, namely, this study is a retrospective study with limited study samples only in a single study centre with a fairly broad inclusion criteria without excluding certain conditions related to condition and diseases that cause hemostasis abnormalities, the hemostasis factors were not tested on the same day in every patient and some of the patients of the sample have been treated from other health facilities so that some patients have received treatment prior to examination of hemostatic factors. There have been many studies abroad that reported hemostatic abnormalities with different variables and outcomes showing the complex pathogenesis of COVID19 which causes coagulopathy conditions.

\section{Conclusions}

Most COVID-19 cases cause coagulopathy conditions, both thrombotic and haemorrhagic events. Early evaluation and monitoring of hemostatic factors especially D-Dimer is necessary to identify hemostatic abnormalities, to determine therapy and to evaluate COVID-19 disease progression. However, considering the risk of poor outcomes, further studies should investigate the prognostic role of hemostatic parameters in COVID-19 patients.

\section{References}

1. WHO. Coronavirus Update. 2020. [cited Oct 29, 2020]. Available from: www.who.int

2. Indonesia Minister of Health. Indonesia Ministry of Health. 2020. Guidelines for the Prevention and Control of Coronavirus Disease (COVID-19). Indonesia Ministry of Health. 0-115. https://infeksiemerging.kemkes.go.id/download/ REV-05_Pedoman_P2_COVID-

19_13_Juli_2020_1.pdf

3. Indonesia's Task Force for COVID-19. Distribution data (internet). [cited: Oct 29, 2020]. Available from:https://covid19.go.id

4. Indonesia's Emerging Infection for COVID-19. Update on the COVID-19 case. [cited: Sept 24, 2020]. Available from:https://infemerging.kemkes.go.id/

5. Fu, Wang, Yuan, et al. 2020.Clinical characteristics of coronavirus disease 2019 (COVID-19) in China: A systematic review and meta-analysis. Journal of Infection, 80:656-665. https://doi.org/10.1016/i.jinf.2020.03.041

6. Nagpal, Narayanasamy, Vidholia, Guo, Shin, Lee, et al. 2020. Imaging of COVID-19 pneumonia: patterns, pathogenesis and advance. Br J Radiol, 93:1-12. https://doi.org/10.1259/bjr.20200538

7. Long, Nie, Xiang, Li, Zhang, Fu, Ren, Liu, Wang, Wu. 2020. D-dimer and prothrombin time are the significant indicators of severe COVID-19 and poor prognosis. BioMed research international, 2020:120. https://doi.org/10.1155/2020/6159720

8. Miesbach, Makris. 2020. COVID-19: coagulopathy, risk of thrombosis, and the rationale for anticoagulation. Clinical and Applied Thrombosis / Hemostasis, 26:1-7. https://journals.sagepub.com/home/cat

9. Connors, Levy. 2020. COVID-19 and its implications for thrombosis and anticoagulation. Blood, The Journal of the American Society of Hematology, $135 \quad$ (23) :2033-2040. http://ashpublications.org/blood/articlepdf/135/23/2033/1743274/bloodbld202000600 0c.pdf

10. Zhang, Yan, Fan, Liu, et al. 2020. D-dimer levels on admission to predict in-hospital mortality in patients with Covid-19. Journal of Thrombosis and Haemostasis, 18 (6) :1324-1329. https://doi.org/10.1111/jth.14859

11. Bilaloglu, Aphinyanaphongs, Jones, Iturrate, Hochman, Berger JS. 2020. Thrombosis in hospitalized patients with COVID-19 in a New York City health system. Jama, 324 (8) :799-801. https://doi.org/10.1001/jama.2020.13372 
12. Sakka, Connors, Hékimian, Martin-Toutain, Crichi, Colmegna, et al. 2020. Association between DDimer levels and mortality in patients with coronavirus disease 2019 (COVID-19): a systematic review and pooled analysis. JMVJournal de Médecine Vasculaire, 45:268-274. https://doi.org/10.1016/j.jdmv.2020.05.003

13. Yu, Li, Chen, Ouyang, Zhang, Zhao, Tang, Luo, Xu, Yang, Huang. 2020. Evaluation of variation in D dimer levels among COVID-19 and bacterial pneumonia: a retrospective analysis. Journal of Thrombosis and Thrombolysis, 10:1-00. https://doi.org/10.1007/s11239-020-02171-y

14. Luo, Xu, Du, Kou, Liao, Cheng, Mei, Hu. 2020. Early coagulation tests predict risk stratification and prognosis of COVID-19. Aging (Albany NY), 12 (16):15918-15937. https://doi.org/10.18632/aging.103581

15. Martín-Rojas, Pérez-Rus, Delgado-Pinos, DomingoGonzález, Regalado-Artamendi, Alba-Urdiales, Demelo-Rodríguez, Monsalvo, Rodríguez-Macías, Ballesteros, Osorio-Prendes. 2020. COVID-19 coagulopathy: an in-depth analysis of the coagulation system. European Journal of Hematology, $105 \quad$ (6):741-750. https://doi.org/10.1111/ejh.13501

16. Luo, You, Lu, Fu. 2020. Characteristics of coagulation alteration in patients with COVID-19. Annals of Hematology, 20:1-8. https://doi.org/10.1007/s00277-020-04305-x

17. Birkeland, Zimmer, Kimchi, Kedan. 2020. Venous Thromboembolism in Hospitalized COVID-19 Patients: Systematic Review. Interactive journal of medical research, 9 (3):1-8. http://www.ijmr.org/2020/3/e22768/

18. Gómez-Mesa, Galindo-Coral, Montes, Martin. 2020. Thrombosis and coagulopathy in COVID-19. PreProof Journal, 1-35. https://doi.org/10.1016/j.cpcardiol.2020.100742

19. Tang, Li, Wang, Sun. 2020. Abnormal coagulation parameters are associated with poor prognosis in patients with novel coronavirus pneumonia. Journal of thrombosis and haemostasis, 18 (4):844-847. https://doi.org/10.1111/jth.14768

20. Srivastava, Garg, Bansal, Kumar. 2020. COVID-19 infection and thrombosis. Clinica Chimica Acta, 510:344-346.

https://doi.org/10.1016/j.cca.2020.07.046

21. Hadid, Kafri, Al-Katib. 2020. Coagulation and anticoagulation in COVID-19. Blood Reviews, 1-10. https://doi.org/10.1016/j.blre.2020.100761

22. Lippi, Favaloro. 2020. D-dimer is associated with severity of coronavirus disease 2019: a pooled analysis. Thrombosis and haemostasis, 120 (5):876-878. https://doi.org/10.1055/s-00401709650

23. Sharp, Ghodke. 2020. D-dimer Levels in COVID-19 Patients and Its Correlation with Age and Gender: A Retrospective Analysis. International Journal of
Research and Review, 7 (7):2454-2237. www.ijrrjournal.com

24. Price, Cabe, Garfield, Wort. 2020. Thrombosis and COVID-19 pneumonia: the clot thickens! European Respiratory Journal, $56 \quad$ (1):1-5. https://doi.org/10.1183/13993003.01608-2020

25. Yao, Cao, Wang, Shi, Liu, Luo, Chen, Chen, Yu, Huang, Hu. 2020. D-dimer as a biomarker for disease severity and mortality in COVID-19 patients: a case control study. Journal of intensive care, 8 (1):1-11. https://doi.org/10.1186/s40560020-00466-z

26. Cho, Mc Clelland, Cheng, Kim, Hu, Zenilman, D'Ayala. 2020. Utility of d-dimer for diagnosis of deep vein thrombosis in coronavirus disease-19 infection. Journal of Vascular Surgery: Venous and Lymphatic Disorders, 1-8. https://doi.org/10.1016/j.jvsv.2020.07.009

27. Di Castelnuovo, De Curtis, Costanzo, Persichillo, Olivieri, Zito, Donati, De Gaetano, Lacoviello. 2020. Association of D-dimer levels with all-cause mortality in a healthy adult population: findings from the MOLI-SANI study. Haematologica, 1; 98 (9): 1476-1480. https://doi.org/10.3324/haematol.2012.083410

28. Berger, Kunichoff, Adhikari, Ahuja, Amoroso, Aphinyanaphongs, Cao, Goldenberg, Hindenburg, Horowitz, Parnia. 2020. Prevalence and Outcomes of D- Dimer Elevation in Hospitalized Patients With COVID-19. Arteriosclerosis, thrombosis, and vascular biology, 40 (10):2539-2547. www.ahajournals.org/journal/atvb

29. Huang, Wang, Li, Ren, Zhao, Hu, et al. 2020. Clinical features of patients infected with the 2019 novel coronavirus in Wuhan, China. Lancet, 395:497-506. https://doi.org/10.1016/S01406736(20)30183-5

30. Jin, Duan, Bao, Gu, Chen, Li, Mao, Chen, Xie. 2020. The values of coagulation function in COVID-19 patients. PLoS ONE, 15 (10):1-12. https://doi.org/10.1371/journal.pone.0241329

31. Cannegieter, Klok FA. 2020. COVID-19 associated coagulopathy and thromboembolic disease: Commentary on an interim expert guidance. Research and Practice in Thrombosis and Haemostasis, 4:439-445. https://doi.org/10.1002/rth2.12350

1. Han, Yang, Liu, Liu, Wu, Li, Liu, Zhu. 2020. Prominent changes in blood coagulation of patients with SARSCoV-2 infection. Clinical Chemistry and Laboratory Medicine (CCLM), 58 (7):1116-1120. https://doi.org/10.1515/cclm-2020-0188 